\title{
REESTRUTURAÇÃO URBANA E CONFORTO TÉRMICO: CENÁRIOS DE MODELIZAÇÃO EM CURITIBA-PR APÓS A COPA DE 2014
}

\author{
SCHMITZ, Lisana Katia - schmitz@ufpr.br \\ Dep. Arquitetura e Urbanismo / UFPR \\ MENDONÇA, Francisco - chico@ufpr.br \\ Dep. Geografia / UFPR
}

\begin{abstract}
Resumo
Curitiba sediará jogos do Campeonato Mundial de Futebol 2014. A cidade é, portanto, alvo de grandes intervenções urbanas, notadamente a construção de novas rotas de transporte visando melhorar a mobilidade urbana, promover o adensamento, a verticalização e a diversificação de usos das edificações ao longo dos respectivos eixos viários. As importantes alterações que, desta forma, serão produzidas na forma urbana provocarão transformações nas condições climáticas urbanas e no conforto térmico. Assim, este texto apresenta resultados relativos à conformação das condições climáticas e de conforto térmico desta cidade, bem como aponta cenários futuros de sua alteração em decorrência das transformações urbanas projetadas. A metodologia da pesquisa é o Sistema Clima Urbano SCU (MONTEIRO, 2003) e está estruturada nos seguintes passos: 1) Modelização da forma e função urbanas; 2) Levantamento de dados de temperatura e umidade relativa do ar em locais previamente definidos com base na tipologia edificada e zoneamento urbano; 3) Construção de cenários para o clima urbano e conforto térmico considerando as transformações urbanas futuras. Para elaboração do estudo foram realizados experimentos em pontos específicos dos dois principais eixos estruturantes da circulação viária em execução na cidade: 1) A Linha Verde e, 2) o Eixo do Metrô. Este estudo visa contribuir para o planejamento de políticas públicas e gestão urbana em Curitiba, para garantir o conforto térmico para a vida urbana.
\end{abstract}

Palavras-chave. Clima urbano, conforto térmico, planejamento urbano, Copa do mundo, Curitiba.

URBAN RESTRUCTURING AND THERMAL COMFORT: SCENERIES OF MODELING IN CURITIBAPR AFTER THE WORLD CUP OF 2014

Abstract

Curitiba will host games of the World Championship of Soccer 2014. The city is, therefore, target of great urban interventions, especially the construction of new transport routes seeking to improve the urban mobility, to promote the densification, the verticalization and the diversification of the use of buildings along the respective road axes. The important alterations that, this way, will be produced in the urban form will provoke transformations in the urban climatic conditions and in the thermal comfort. Like this, this text presents relative results to the conformation of the climatic conditions and of thermal comfort of this city, as well it points as future sceneries of their amendment as consequence of the urban transformations designed. The methodology of the research is the Urban Climate System UCS (MONTEIRO 2003) and it is structured in the following steps: 1) modelling of the form and urban function; 2) survey data of temperature and relative humidity of the air in places previously defined with base in the built typology and urban zoning; 3 ) construction of sceneries for the urban climate and thermal comfort considering the future urban transformations. For development of the study were accomplished experiments on specific points of two main structural axes of the traffic circulation in execution in the city: 1) the Green Line; and 2) the Axis of the Subway. This study aims to contribute for the public policy planning and urban management in Curitiba, to guarantee the thermal comfort for the urban life.

Keywords: urban climate, thermal comfort, urban planning, World Cup, Curitiba.

\section{INTRODUÇÃO}

A globalização repercute de distintas maneiras sobre a sociedade atual e futura; no Brasil ela alavancou um processo controverso, pois ao mesmo tempo em que as cidades se tornam desprovidas de bens e serviços básicos, encerrando em si contradições e desigualdades, tornam-se objeto 
de ostentação de uma nova arquitetura, moeda de forte valorização no mercado imobiliário internacional, um produto no competitivo mercado mundial de cidades, elementos estes encontrados no modelo-Curitiba (MOURA, 2009, p.68). Um dos seus marcos é constituído pela realização de eventos de grande envergadura, tal como a copa do mundo de futebol de 2014 que será realizada no Brasil e da qual Curitiba será uma das cidades sede. Por este motivo, estão sendo desenvolvidas diversas obras de infraestrutura para atendimento ao público da Copa de 2014 e aos cidadãos, tais como: a reforma do estádio Joaquim Américo Guimarães, do Clube Atlético Paranaense; a adequação do aeroporto internacional Afonso Pena com o aumento da capacidade de atendimento, além de ampliação do terminal de passageiros e do pátio de aeronaves; melhorias no sistema viário da cidade buscando maior conectividade com cidades e estados vizinhos; além de projetos como a construção do Metrô e da Linha Verde.

Estes dois projetos, em fase de implantação, terão importante papel na preparação da cidade para sediar a Copa do Mundo de Futebol de 2014, favorecendo a mobilidade urbana e a circulação dos turistas que virão para o evento. Por esse motivo parte dos recursos financeiros envolvidos na sua realização virá do governo federal, oriundos do Plano de Aceleração do Crescimento para a Copa de 2014 (PAC da Copa) cujo foco principal é a mobilidade urbana. Tais projetos de reestruturação trarão benefícios e poderão atender aos vários desafios impostos ao planejamento urbano de Curitiba no final do século $\mathrm{XX}$ e início do XXI, tanto atendendo as demandas criadas pela Copa de 2014, como as relativas ao crescimento da cidade. Os projetos deverão: 1) promover a integração com os municípios da RMC; 2) readequar o zoneamento urbano para atender ao crescimento da população para as próximas décadas; 3) ampliar a capacidade do sistema de transporte coletivo (um dos principais trunfos do planejamento urbano de Curitiba em iminente esgotamento); e, 4) desafogar o sistema viário e facilitar a mobilidade urbana.

Por outro lado, as intervenções propostas por ambos os projetos, o Metrô e a Linha Verde, que têm importante papel de indução do crescimento e desenvolvimento urbano, gerarão repercussões em outras dimensões como na tipologia edificada, na forma urbana, na criação de novos fluxos, no clima urbano e no conforto térmico, dentre outros.

\section{ANTECEDENTES E OBJETIVOS}

A partir da década de 1970 o Brasil experimentou um movimento de desconcentração da produção industrial que ocasionou um rearranjo do trabalho em seu território, sobretudo no sul do país, o que resultou num acelerado movimento de expulsão de trabalhadores rurais, os quais passaram a se deslocar não só para as áreas de fronteira agrícola, como também para as cidades (SANTOS; SILVEIRA, 2008, p.106). A esse fenômeno de urbanização, a partir dos anos 1990, soma-se a competitividade pela inserção na economia internacional, processo no qual a Região Metropolitana de Curitiba (RMC) se destaca como ponto privilegiado do Estado. 
Em conseqüência deste processo, a parcela da população paranaense residindo na RMC passou de 27,5\%, em 1991, para 31,9\% em 2000, 37,5\% em 2010 e deverá ser de 44\% em 2020 (PMC, 2008, p.32). Embora a polaridade da RMC deva persistir, a centralidade deverá desdobrar-se do município de Curitiba para cidades vizinhas dentro da RMC, tais como São José dos Pinhais, Colombo, Piraquara e Fazenda Rio Grande (PMC, 2008, p.33), reforçando, desta forma, a importância da integração metropolitana, viabilizada pela implantação dos projetos da Linha Verde e do Metrô curitibano.

Neste contexto, mediante a Lei Municipal $n^{0} 9800 / 2000$, alterou-se a configuração linear da cidade para pluriaxial e, visando o horizonte futuro de crescimento populacional, foram definidos novos eixos de adensamento. Estavam incluídos novos parâmetros de Uso e Ocupação do Solo para os terrenos ao longo do trecho urbano da antiga rodovia BR-116, que está sendo integrado à malha urbana e transformado no sexto eixo de transporte curitibano: a Linha Verde (Figura 1), cujos parâmetros urbanísticos visam o adensamento populacional e a verticalização.
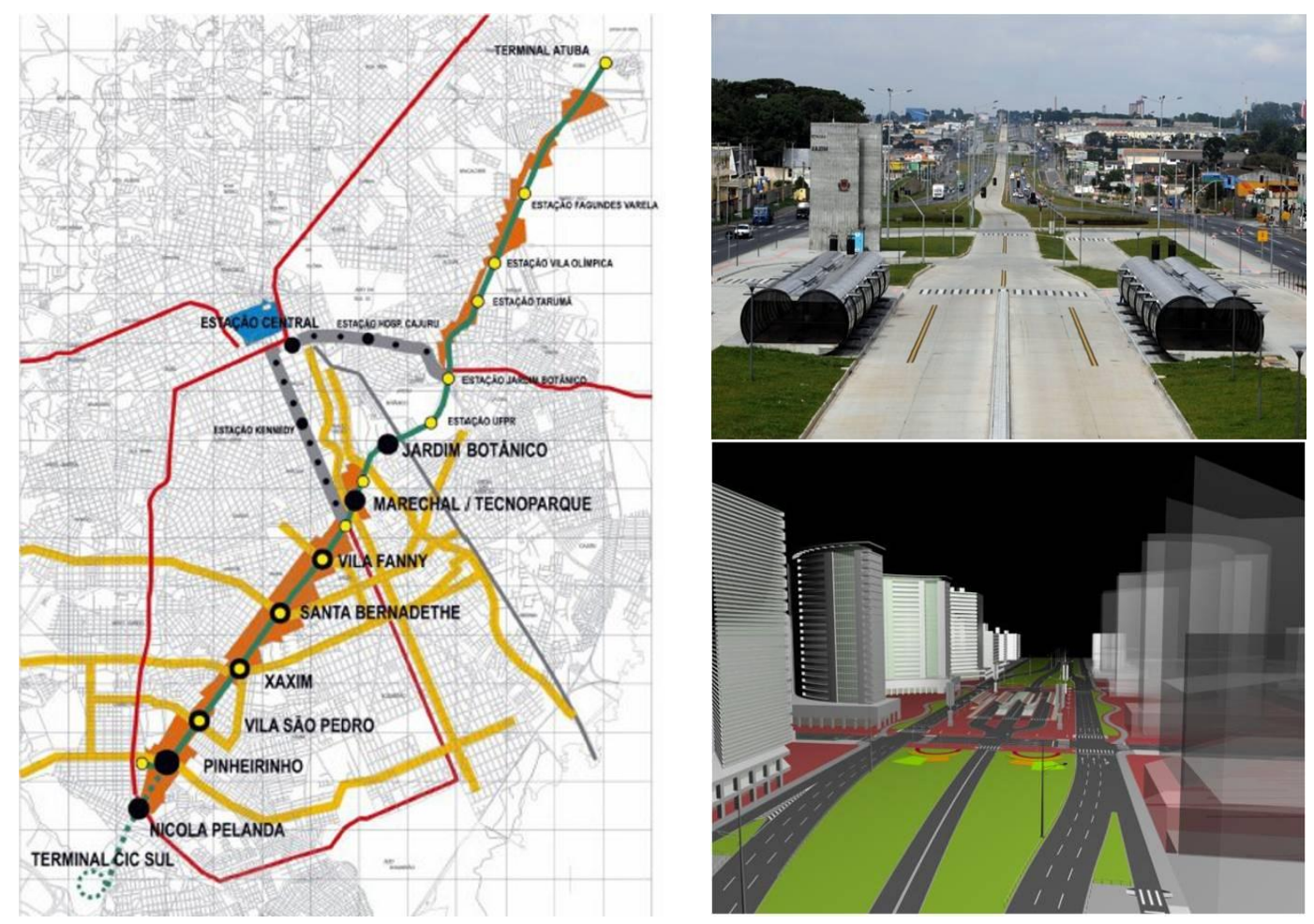

A estrutura básica do sistema de transporte coletivo de Curitiba compõe-se de seis eixos, além dos terminais de integração e das estações-tubo. Os eixos de transporte (Norte, Sul, Leste, Oeste e Boqueirão) localizam-se nos corredores estruturais, e contam com espaço exclusivo destinado à circulação das linhas expressas, por meio de canaletas exclusivas. A Linha 
Verde, sexto corredor da Rede Integrada de Transporte (RIT), integrará a porção leste da cidade e contribuirá para a integração metropolitana (tanto ao norte como ao sul). Quando finalizada deverá totalizar uma extensão de 18 quilômetros, beneficiando vinte e três bairros e 287 mil habitantes (PMC, 2008).

O atual eixo Norte-Sul da RIT deverá ser substituído pela Linha Azul do Metrô Curitibano (Figura 2), a qual também fará a integração metropolitana, ao sul com o município de Fazenda Rio Grande e ao norte com o município de Colombo. O traçado em estudo terá extensão de 23 quilômetros, contemplando trechos aéreos e subterrâneos, e proporcionará um incremento de $20 \%$ no número de passageiros transportados atualmente.
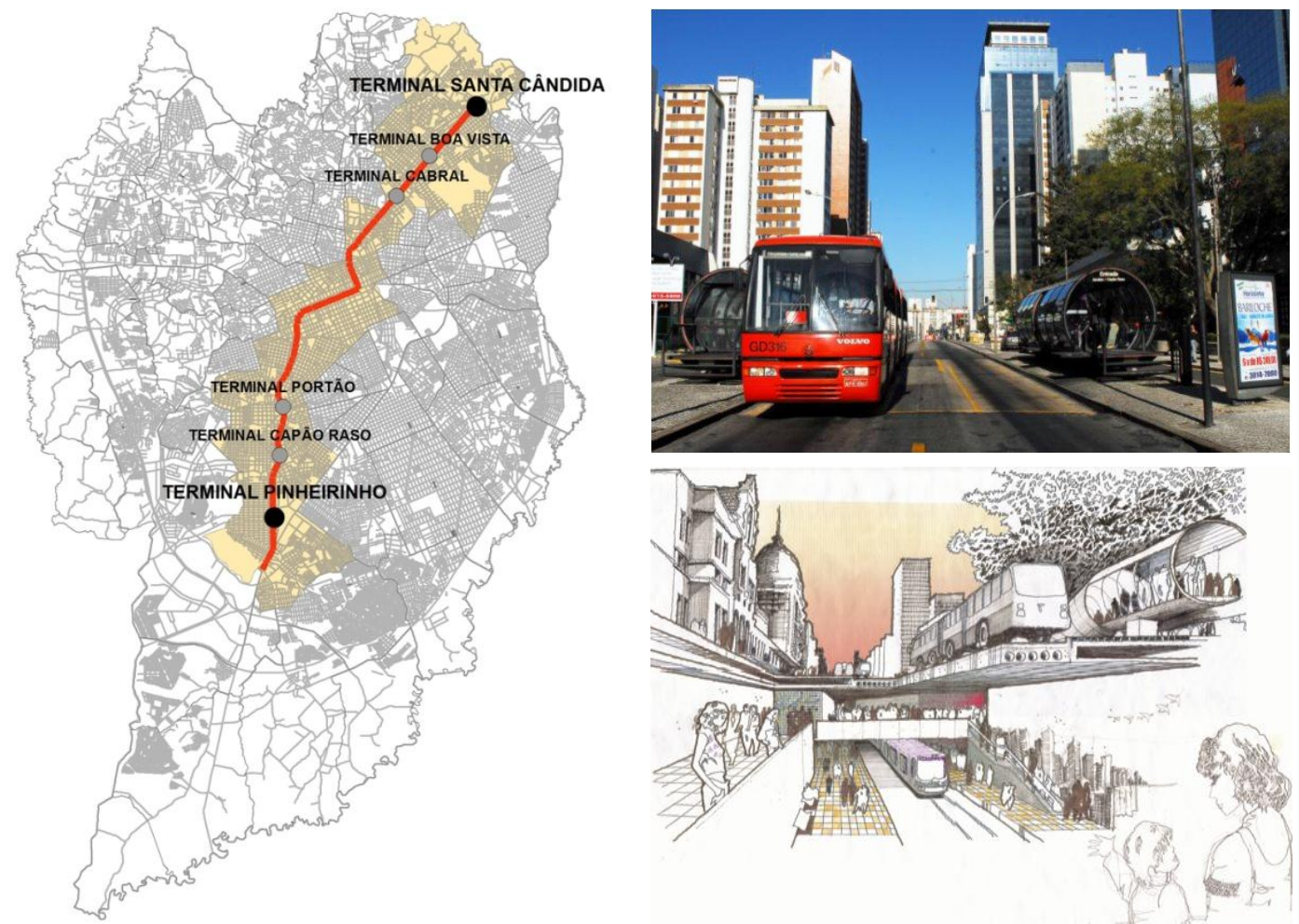

Figura 2. Curitiba/PR: Trajeto do Metrô; Eixo Norte-Sul; Projeto do Metrô.

Fonte: IPPUC (2011).

Com a implantação do metrô, a área da canaleta exclusiva, hoje utilizada pelo ônibus biarticulado, deverá ser totalmente reurbanizada. A área antes ocupada pelas canaletas de uso exclusivo do transporte coletivo receberá novos usos e equipamentos: "abrigará ciclovia, calçadão para pedestres, arborização e equipamentos de lazer". Nas áreas onde serão construídas as estações, quiosques comerciais, também as bilheterias e demais estruturas necessárias ao funcionamento do metrô (METRÔ CURITIBANO, 2011).

À medida que as novas opções de transporte coletivo, por ônibus na Linha Verde ou futuramente por meio da primeira linha de metrô previsto ao longo 
do Eixo Estrutural Norte-Sul, induzam à consolidação da ocupação dos terrenos adjacentes a estes eixos, o clima intraurbano nestas áreas terá expressivas alterações e um novo cenário topo-microclimático poderá se conformar em Curitiba. Portanto, são objetivos do presente trabalho investigar e discutir as propostas apresentadas, assim como construir cenários de clima urbano e conforto térmico, com base na modelagem do Sistema Clima Urbano - SCU, tendo em vista as expressivas transformações previstas para a cidade e seus possíveis impactos sobre o clima urbano e o conforto térmico.

\section{CLIMA E CONFORTO TÉRMICO EM CURITIBA}

O estudo do clima de uma área determinada requer a compreensão dos controles climáticos aos quais está submetido. A escala climática implica uma ordem hierárquica e uma relação entre as dimensões espacial (extensão) e temporal (duração) do fenômeno a ser investigado, pois "a interação dos controles atmosféricos com os fatores geográficos do clima determina o dinamismo do fluxo de energia que se dá em áreas diferentes do espaço terrestre" (MENDONÇA; DANNI-OLIVEIRA, 2007, p. 22; p. 83). Curitiba, localizada ao sul do Trópico de Capricórnio e a 920m de altitude, em área de domínio do Clima Tropical de Altitude (mesotérmico), se encontra na rota de atuação de sistemas atmosféricos intertropicais e polares: Massa de ar Tropical Atlântica (TA), Polar Atlântica (PA), Tropical Continental (Tc) e Equatorial Continental (Ec), apresenta temperaturas médias no verão por volta dos $20^{\circ} \mathrm{C}$. Contudo, no inverno, as temperaturas alcançam valores baixos para os padrões tropicais: as médias são de $13^{\circ} \mathrm{C}$ em junho e julho e a mínima absoluta já atingiu a $-5,2^{\circ} \mathrm{C}$, em junho de 1972. A cidade é considerada úmida (aproximadamente $1.600 \mathrm{~mm}$ anuais de chuva) e fria, com grande amplitude térmica diária e anual, e tempo frequentemente instável (MENDONÇA; DANNI-OLIVEIRA, 2007).

Conforme o Zoneamento Bioclimático Brasileiro estabelecido pela NBR 15220-3 (ABNT, 2005), Curitiba se encontra na mais fria das oito zonas climáticas brasileiras, a zona bioclimática 1 , que corresponde a apenas $0,8 \%$ do território nacional. Sendo a mais fria entre as capitais brasileiras, apresenta desconforto térmico por frio durante a maior parte do ano, porém com mais intensidade no inverno.

O clima urbano é resultante da interação entre processos naturais e atividades humanas. A urbanização altera o ambiente natural e a qualidade de vida na cidade mediante supressão da vegetação nativa, impermeabilização do solo, adensamento populacional e de construções, emissão de poluentes, entre outros, afetando as condições climáticas locais e gerando um clima particular. Assim, o espaço construído, aliado às atividades humanas, promove uma alteração do campo térmico natural que tende a formar "ilhas de calor" (IC) e/ou "ilhas de frescor" (IF) ao longo do tecido urbano.

Os termos IC e IF foram empregados por vários estudiosos, dentre os quais se destacam Oke (1988) e Escourou (1991), e estão diretamente associados à formação de situações particulares de conforto e de desconforto ambiental nas cidades. As propriedades térmicas dos materiais, a estrutura, forma e funções urbanas, além da movimentação do 
ar no canopy layer, estão diretamente associadas ao fenômeno urbano da IC/IF. Todavia a cidade troca influências com seu entorno e forma o urban boundary layer (OKE, 1988) pois, conforme Monteiro (1990, p.10) ela é "uma contínua, cumulativa e acentuada 'derivação antrópica' do ambiente", implicando em "uma série de alterações sobre a atmosfera - até mesmo em sua própria composição química - tanto 'sobre ela' e até mesmo como 'exportação' para o ambiente circundante".

Geiger (1990, p. 506-508) ressalta ainda a importância da situação topográfica da cidade na definição do seu próprio clima. Assim, se ela estiver situada em um vale, abrigada dos ventos, as diferenças urbanorurais do clima serão mais significativas do que se estiver num planalto, exposta ao vento. As características do clima urbano também serão diferentes em situações de encosta ou a beira-mar. Da mesma forma, o clima dentro de uma cidade de topografia variada não pode ser tomado como homogêneo. O clima urbano é alterado pela interação das situações sinóticas com as características físicas do sítio e do construto urbano, a vegetação e o calor antropogênico, diferenciando as condições climáticas intraurbanas e assim, os graus de conforto térmico.

Danni-Oliveira (2000) analisou a variabilidade dos parâmetros físicoquímicos no âmbito da camada de ar intraurbano (canopy layer), resultante da dinâmica atmosférica regional e da configuração e da funcionalidade da cidade de Curitiba, no inverno. A espacialização dos contaminantes do ar na cidade se revelou de forma singular diante de uma estrutura urbana em que a tipologia edificada (conformando cânions urbanos) tende a confinar os poluentes. A ação dos ventos, combinada às características morfo-estruturais dos Eixos Estruturais, formou áreas ora concentradoras, ora receptoras ou canalizadoras de contaminantes (cânion das edificações). No caso destas áreas o adensamento das torres residenciais sem recuos entre elas impede a permeabilidade para a ação dos ventos, desfavorece a dispersão dos poluentes e induz à geração de contaminantes pelo aumento do fluxo de veículos. Desta forma, relacionam-se o fluxo de veículos, a ação transportadora do vento e sua interação com as edificações e os aspectos espaciais de qualidade do ar da camada intraurbana de Curitiba.

Os efeitos da implantação dos Eixos e Setores Estruturais se revelam na intensidade de suas alterações. O desconforto ambiental e a poluição atmosférica agravaram-se pela geometria urbana e intensa urbanização. Ao longo dos Eixos Estruturais, criados para direcionar o crescimento da cidade e o fluxo de veículos, o zoneamento proporcionou a construção de altos edifícios que formam cânions urbanos alterando os campos térmicos, a iluminação natural, a ventilação e a qualidade do ar (DANNI-OLIVEIRA, 2000).

Estudos sobre a poluição do ar em Curitiba evidenciaram que a cidade já apresenta problemas de saúde pública ligados aos contaminantes presentes no ar; notadamente em relação a morbidade por doenças respiratórias em crianças (BAKONIY E DANNI-OLIVEIRA, 2004, entre outros). Suga (2005) averiguou a incidência solar nos cânions urbanos contidos no Setor Estrutural, em diferentes orientações solares e seu 
potencial para maior aproveitamento das condições de iluminação para prédios contidos nestes eixos. Como a legislação do Setor Estrutural não estabelece limitação de altura ou parâmetros como orientação axial e latitude, são bastante prejudicadas as condições de iluminação e a incidência solar em situações críticas como durante o período de inverno em ambientes de primeiro pavimento. Este fato poderia ser amenizado, como ressalta Assis (2002) caso houvesse uma legislação de uso do solo com limitação de alturas e dispositivos que garantissem o acesso ao Sol e à luz o que em tese favoreceria um melhor uso da energia solar na forma de calor e iluminação.

A variabilidade térmica na porção central da mancha urbana da Região Metropolitana de Curitiba foi constatada por Mendonça e Dubreuil (2006). Ao investigarem o clima desta área mediante dados meteorológicos e compará-los a análise de imagens do satélite, os autores encontraram uma considerável variabilidade dentro da mancha urbana, com alternâncias entre IFs (Ilhas de frescor) e ICs (Ilhas de calor) na área urbanizada, resultando em diferentes graus de conforto térmico, ainda que se apresente como uma mancha mais quente e homogênea do que a área rural circunvizinha. Destacam-se no campo térmico, os efeitos da urbanização, da industrialização, da densidade da cobertura vegetal e da topografia.

A partir da análise dos aspectos do sítio e do fato urbano relacionada a análise temporal (baseada em medições meteorológicas, imagens de satélite), Dumke (2007) caracterizou o clima intraurbano/graus de conforto térmico e seu impacto sobre as condições e qualidade de vida em Curitiba. Esta cidade, dadas as suas dimensões e a heterogeneidade de suas características, não se configura a priori apenas uma IC. Sua estrutura e forma urbanas diferem daquelas das cidades tradicionais, em que a área comercial e verticalizada (Commercial Building Downtown - CDB) se localiza no centro, ao redor do qual a densidade urbana se reduz gradativamente. A variabilidade do clima intraurbano em Curitiba reflete a geometria urbana marcada por eixos lineares verticalizados, a urbanização polinucleada, os diferentes graus de densidade urbana e as áreas verdes distribuídas de forma desigual. Ainda assim, a gênese do clima urbano, inclui o processo de formação da IC, sendo esperado que as temperaturas sejam mais baixas na periferia, o quê, de forma geral, se confirma. Na periferia a amplitude térmica tende a ser maior do que no centro urbano, causada, inclusive, pela menor inércia térmica das construções, fazendo coincidir, neste local, um duplo desconforto (por frio e amplitude térmica).

$\mathrm{Na}$ porção central da mancha urbana, desde o município pólo (Curitiba), e estendendo-se aos vizinhos, a configuração espacial da cidade hoje é marcada por uma maciça verticalização ao longo dos Eixos Estruturais (Figuras 3 e 4), que transformou de forma radical o sistema urbano préexistente, causando um importante impacto ambiental na paisagem urbana, no clima urbano e nos aspectos do conforto térmico. 


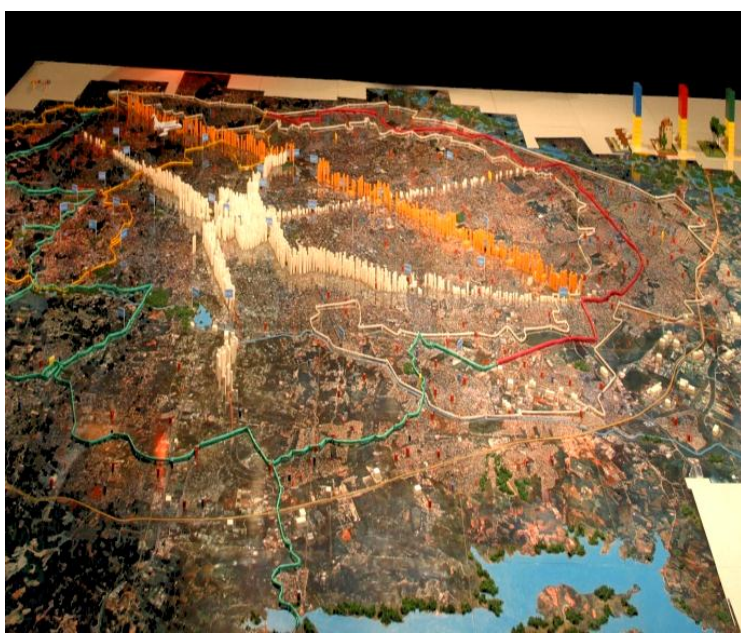

Figura 3. Curitiba/PR: Maquete com Eixos Estruturais.

Fonte: IPPUC (2011).

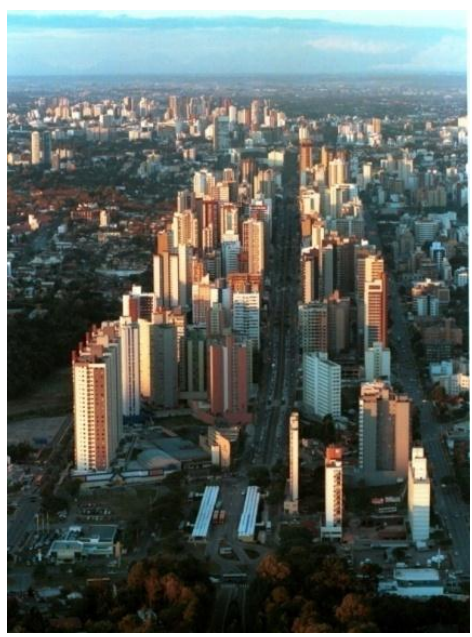

Figura 4. Curitiba/PR: Eixo Estrutural Noroeste

Fonte: IPPUC (2011)

\section{CLIMA URBANO/CONFORTO TÉRMICO EM CURITIBA E MUDANÇAS GLOBAIS: ALGUMAS PERSPECTIVAS}

Os impactos da urbanização associada às interações atmosféricas se evidenciaram em duas avaliações bioclimáticas para Curitiba: a primeira, realizada por Goulart et al. (1998), a partir dos dados horários do TRY (Test Reference Year) para a dédada 1961-1970 e dos parâmetros de Givoni (1992), revelou que $73,2 \%$ das horas anuais em Curitiba eram de desconforto por frio, ou seja, abaixo de $18^{\circ} \mathrm{C}$.

Por sua vez, Rossi et al. (2009), atualizaram o TRY para a década 19982007 e compararam os resultados encontrados aos obtidos anteriormente por Goulart et al. (1998). As médias das temperaturas mensais entre os $T R Y$ respectivamente encontrados (1969 e 2001) evidenciaram o aumento médio de temperatura de $1,9^{\circ} \mathrm{C}$, significativo para um período de 32 anos. Comparando os graus de conforto/desconforto a partir da análise dos diagramas de conforto de Givoni (1992), a porcentagem de conforto (entre $18^{\circ}$ e $29^{\circ} \mathrm{C}$ ) em 2001 aumentou $20 \%$ em relação a 1969 , com o aumento das temperaturas médias e mínimas.

Para Rossi et al. (2009), é possível que a elevação das temperaturas tenha sido causada principalmente pelo acelerado crescimento urbano de Curitiba e sua conurbação com as cidades vizinhas, que se deu justamente neste período. Entre 1969 e 2006 a população da mancha urbana aumentou em cerca de quatro vezes (COMEC, 2010). Ainda assim, o desconforto térmico por frio em Curitiba continua rigoroso e predominando em $53.30 \%$ das horas anuais.

Para Oke (1978) e Assis, (2000), o estudo do clima urbano pode ser tomado como modelo em escala reduzida das modificações climáticas não intencionais que as ações humanas podem provocar no clima no futuro, visando à compreensão de seus complexos mecanismos e de seus efeitos sobre o ser humano e a natureza numa escala planetária. A terra, conforme Marengo (2009, p. 407-408), sempre passou por ciclos naturais 
de aquecimento e resfriamento. Períodos de intensa atividade geológica lançaram à superfície quantidades colossais de gases que formaram, várias vezes, uma espécie de bolha grossa sobre o planeta - um efeito estufa natural. Mas, atualmente, a atividade industrial afeta o clima terrestre em sua variação natural, o que sugere que a atividade humana é um fator determinante para o aquecimento.

Para Who (2005), os efeitos das prováveis mudanças climáticas trarão sérias conseqüências para as regiões tropicais. A população urbana será exposta ao efeito combinado de aquecimento global e aquecimento das cidades (fenômeno da ilha de calor). Cabe destacar que uma das conseqüências previstas das mudanças climáticas está atrelada ao incremento da variabilidade dos climas, o que para Curitiba pode acarretar na intensificação e/ou freqüência de situações de temperaturas extremas.

Questionando o aquecimento global antropogênico, Molion (2006) afirma que outros fatores têm maiores influencias na temperatura da Terra. Segundo ele, em função do ritmo das atividades solares e da Oscilação Decadal do Pacífico, o planeta estaria iniciando, a partir de 1998, um período de resfriamento.

Para Mendonça (2007), o tema da intensificação do aquecimento planetário permanece ainda envolto de incertezas. Porém, quaisquer que sejam as mudanças climáticas e sua intensidade, elas ocorrerão de maneira diferenciada no espaço e no tempo. As cidades, por suas diferentes estruturas, morfologias, funções e dinâmicas apresentam consideráveis desafios aos estudiosos e gestores urbanos. Elas são, por excelência, os principais lugares nos quais o jogo recíproco de influencias das mudanças climáticas trará/sofrerá mais intensos impactos; é nelas que os riscos e as vulnerabilidades socioambientais às mudanças climáticas são mais preocupantes, pois envolvem um numero expressivo de pessoas.

\section{MÉTODOS E PROCEDIMENTOS DA PESQUISA}

O monitoramento do campo e conforto térmico de Curitiba envolveu três quadras situadas nas zonas de Uso e Ocupação do Solo existentes nos percursos do metrô e da Linha Verde. Realizaram-se medições (Figura 5) em dois períodos: dias 22 a 25 de fevereiro de 2011 (verão) e 10 a 12 de agosto de 2011 (inverno), objetivando a pré-analise dos dados microclimáticos coletados em locais distintos da cidade. Foram selecionadas duas quadras urbanas já consolidadas no Setor Estrutural (Quadra A) e na Zona Residencial 4 (Quadra B) ambas com tipologia edificada semelhante àquela proposta para a Linha Verde (Quadra C) - Figura 5. Estes dados permitirão simular cenários da configuração climática para os eixos do Metrô e Linha Verde após a consolidação da tipologia edificada. 


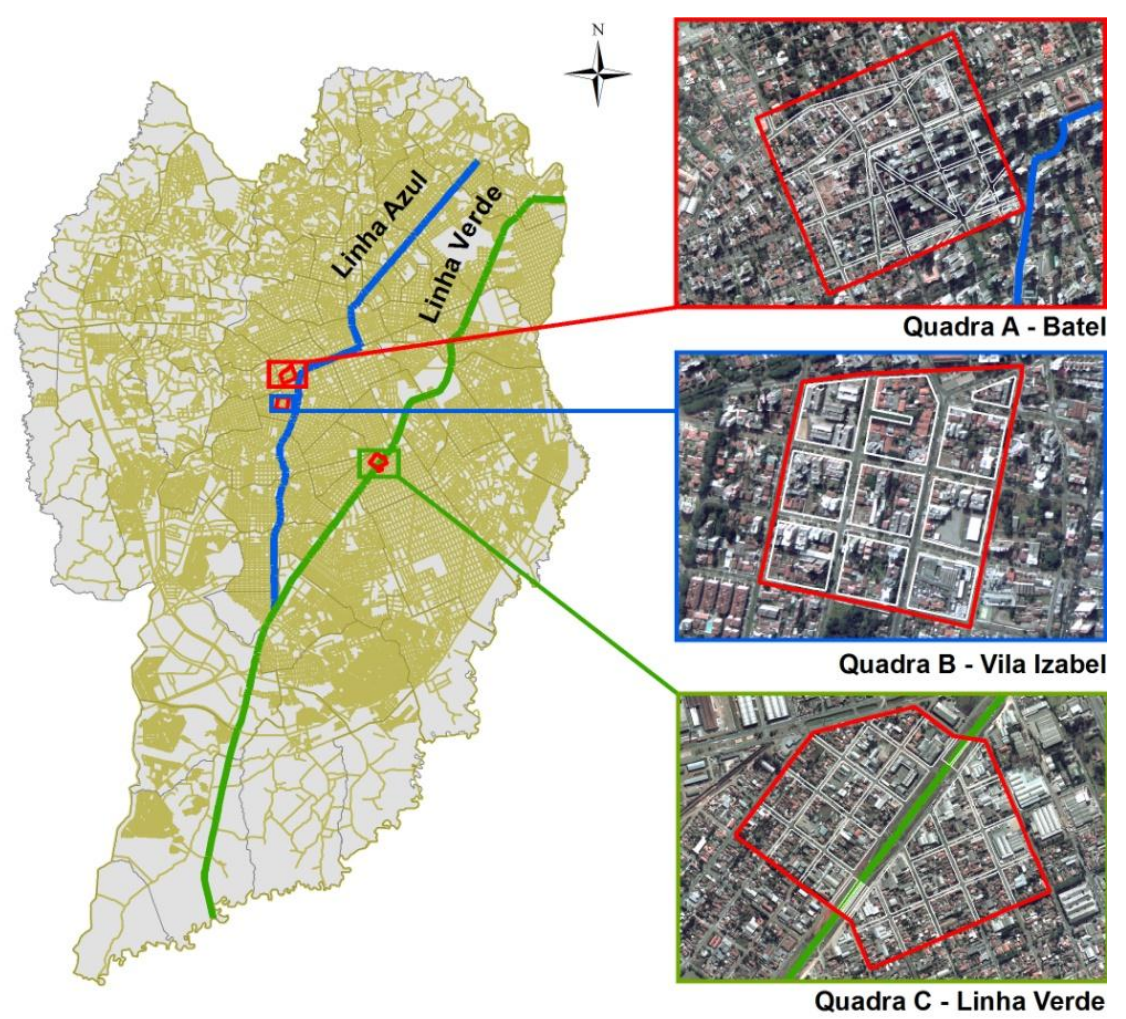

Figura 5. Curitiba/PR: Locais de monitoramento climático ao longo do Eixo do Metrô e da Linha Verde (Quadra A, B e C).

Foram coletados dados nas quatro faces da quadra e em dois de seus cruzamentos, em três horários diários: 7-8h, 15-16h e 19-20 horas. Utilizaram-se abrigos meteorológicos em madeira cujos pés, em cruz, indicam a direção do vento. Nos abrigos foram instalados equipamentos armazenadores de dados (data loggers) do tipo HOBO, para coletar dados de temperatura do ar, bem como os sensores dos termohigrometros digitais e fita para indicar a direção do vento. Utilizaram-se ainda anemômetros digitais, para a verificação da velocidade do vento e termômetros infravermelhos a laser, para a leitura das temperaturas de superfície. Os dados coletados e observados, de nebulosidade (céu claro, parcialmente encoberto e coberto) além da contagem do número de carros em movimento na via nos três minutos que antecederam as medições, foram então anotados em planilhas.

A construção de cenários de conforto térmico, tendo em vista as importantes transformações previstas para cidade, constitui um dos principais objetios deste estudo. Os procedimentos adotados nesta etapa da pesquisa levam em conta a ocupação atual das áreas selecionadas para a aplicação de cenários futuros, em face da esperada modificação estrutural e de adensamento decorrentes da consolidação da Linha Verde e a implantação do Metrô. Para tanto são desenvolvidos nesta etapa: a) Modelização da forma e função urbanas decorrentes da implantação da Linha Verde e do Metro; b) Levantamentos de dados climáticos em locais previamente definidos em função da densidade, morfologia e função 
urbana; e, c) Construção de cenários (modelização) de conforto ambiental urbano considerando as transformações urbanas a serem implementadas.

\section{RESULTADOS PARCIAIS E CENÁRIOS}

Os dados coletados tanto no inverno como verão comprovaram a alta relação entre temperatura, nebulosidade e umidade. Nos dias de nebulosidade variável a alta, a umidade manteve-se acima dos $70 \%$ nos períodos matinal (7-8h) e noturno (19-20h) e as temperaturas permaneceram mais estáveis variando de $1^{\circ}$ a $3^{\circ} \mathrm{C}$ na leitura horária tanto no inverno como no verão, situando-se entre $13^{\circ}$ e $16^{\circ} \mathrm{C}$ no inverno e entre $22^{\circ}$ e $25^{\circ} \mathrm{C}$ no verão. Por outro lado, nos períodos em que a umidade situou-se próxima e abaixo dos $50 \%$, usualmente nas leituras vespertinas (15-16h), apresentaram-se as maiores amplitudes térmicas horárias variando de $1^{\circ}$ a $2^{\circ} \mathrm{C}$ em média no inverno e de $5^{\circ}$ a $8^{\circ} \mathrm{C}$ no verão, situando-se entre $22^{\circ}$ e $24^{\circ} \mathrm{C}$ em média no inverno e $22^{\circ}$ e $30^{\circ} \mathrm{C}$ no verão.

A amplitude térmica diária máxima registrada nos dias de nebulosidade variável foi dos $12^{\circ}$ aos $30^{\circ} \mathrm{C}$ no inverno na face oeste da quadra e dos $22^{\circ}$ aos $30^{\circ} \mathrm{C}$ no verão, sendo, portanto verificada a maior amplitude justamente no inverno. Já nos dias em que predominou a nebulosidade de $100 \%$ a amplitude térmica variou aproximadamente dos $14^{\circ}$ aos $17^{\circ} \mathrm{C}$ no inverno e dos $22^{\circ}$ aos $24^{\circ} \mathrm{C}$ no verão. Constatou-se também, como se pode verificar nas Figuras 6 e 7 , que as maiores temperaturas do ar e das superfícies predominaram nos pontos da Quadra C - Linha Verde - e as menores na Quadra A - Eixo Estrutural do Batel. As baixas temperaturas desta última relacionam-se, dentre outros, aos efeitos dos cânions urbanos e ao sombreamento causado tanto pelas edificações de 15 a 25 pavimentos predominantes nesta área como pela frondosa arborização nas vias.

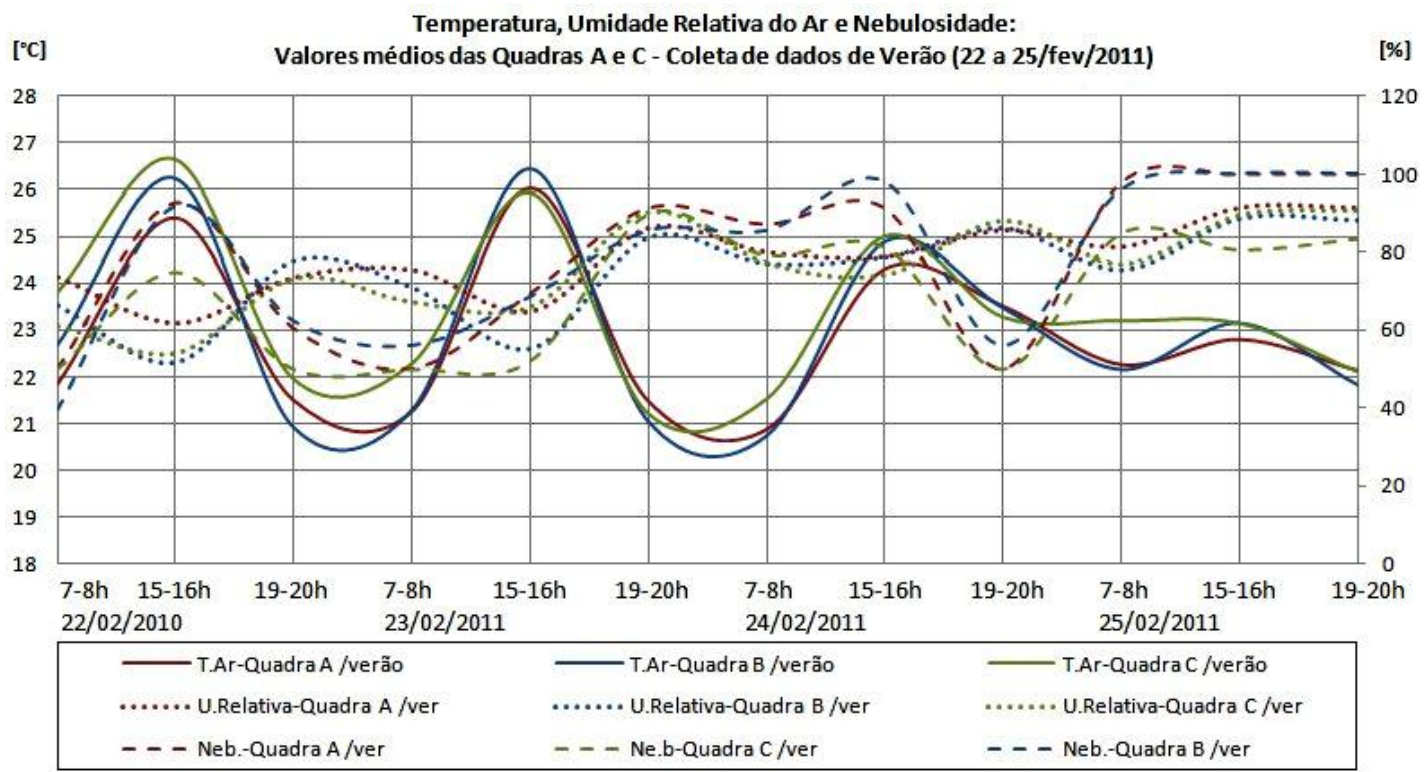

Figura 6. Curitiba/PR: Temperatura, Umidade Relativa e Nebulosidade para as Quadras A, B e C - Verão/2011. 


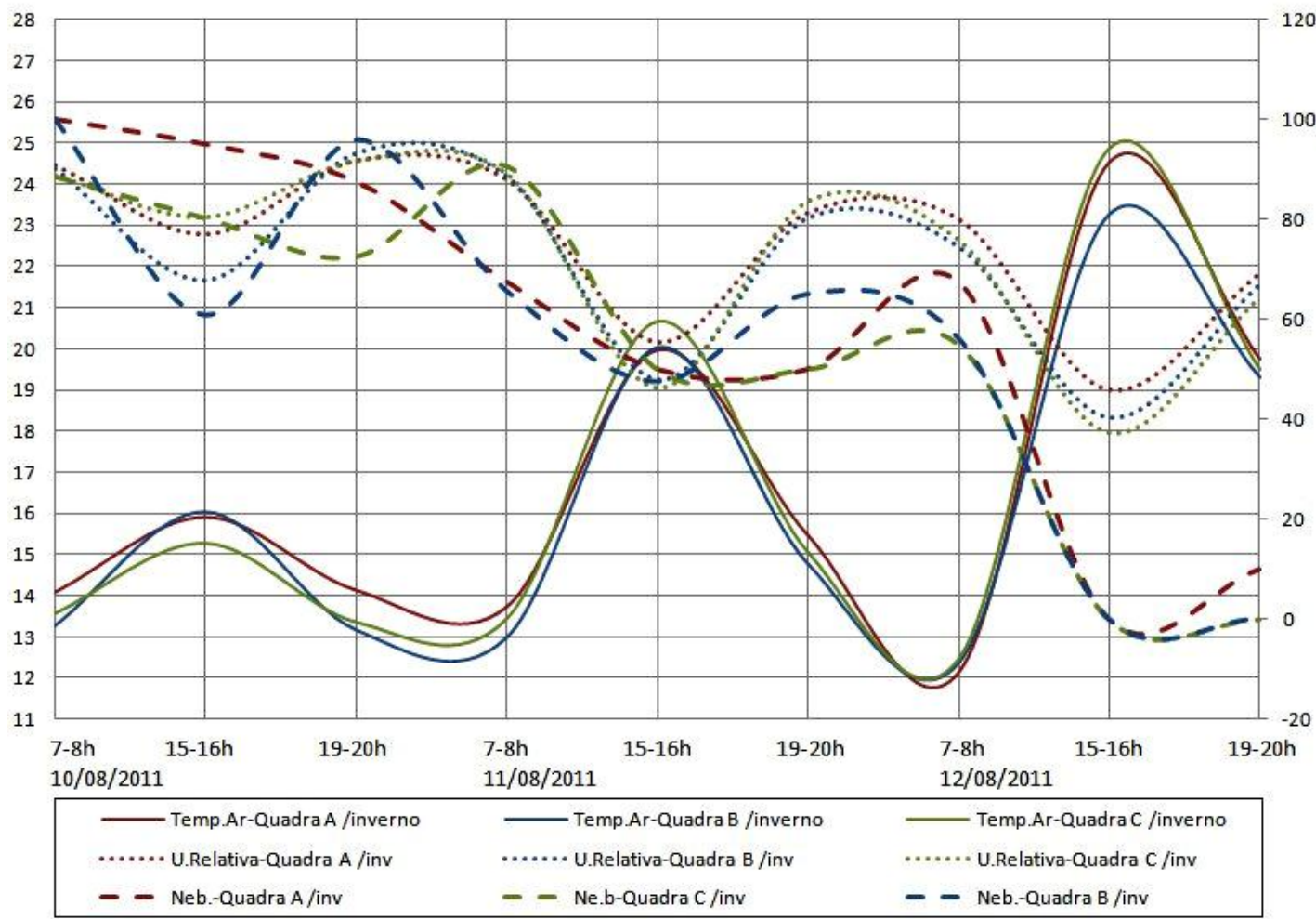

Figura 7. Curitiba/PR: Temperatura, Umidade Relativa e Nebulosidade para as Quadras A, B e C - Inverno/2011.

No que diz respeito às superfícies, em todas as quadras avaliadas, as paredes consideradas eram de alvenaria de tijolos, as calçadas em pedra ou asfalto e o pavimento das ruas sempre em asfalto, ou seja, materiais de baixos valores de refletância solar, altos valores de condutividade térmica e capacidade calorífica. Superfícies que apresentam temperaturas mais elevadas e cujos efeitos são mais intensos nos dias claros e calmos, características que foram percebidas durante as medições e confirmadas pelos valores obtidos.

$\mathrm{O}$ aquecimento das superfícies (parede, calçada e asfalto) mostrou-se mais intenso na Quadra C - na Linha Verde - do que o na Quadra A, em todos os horários medidos tanto no verão como no inverno. Na medição vespertina, das 15 as 16 horas foram constatados os valores mais expressivos de aquecimento das superfícies em relação à temperatura do ar e especialmente na calçada e na rua. Nestas os valores de temperatura chegaram a situar-se em média $4,5^{\circ} \mathrm{C}$ acima da temperatura do ar no verão e até $6,2^{\circ} \mathrm{C}$ em média no inverno. Na Quadra A - no Batel - os valores médios de temperatura da superfície da calçada e da rua, embora também superiores à temperatura do ar, atingiram menor elevação: foram de até $2,4^{\circ} \mathrm{C}$ acima da temperatura do ar no verão e até $2,7^{\circ} \mathrm{C}$ acima no inverno. Essa diferença pode ser constatada quando observando as variações dos valores dos gráficos apresentados nas Figuras 8 e 9 . 
As diferenças observadas podem ser facilmente compreendidas quando consideradas a tipologia edificada e a representatividade da arborização nas diferentes quadras (Figuras 10 e 11), pois os materiais presentes nas superfícies são muito semelhantes. Na Quadra A, onde tanto há maior sombreamento provocado pelos edifícios (15 a 25 pavimentos) como presença de arborização de grande porte nas ruas e lotes, foram obtidas as menores temperaturas de superfícies, até mesmo do que na Quadra B - Vila Izabel ocupada por edifícios de 6 a 8 pavimentos e com arborização em menor quantidade e de menor porte.
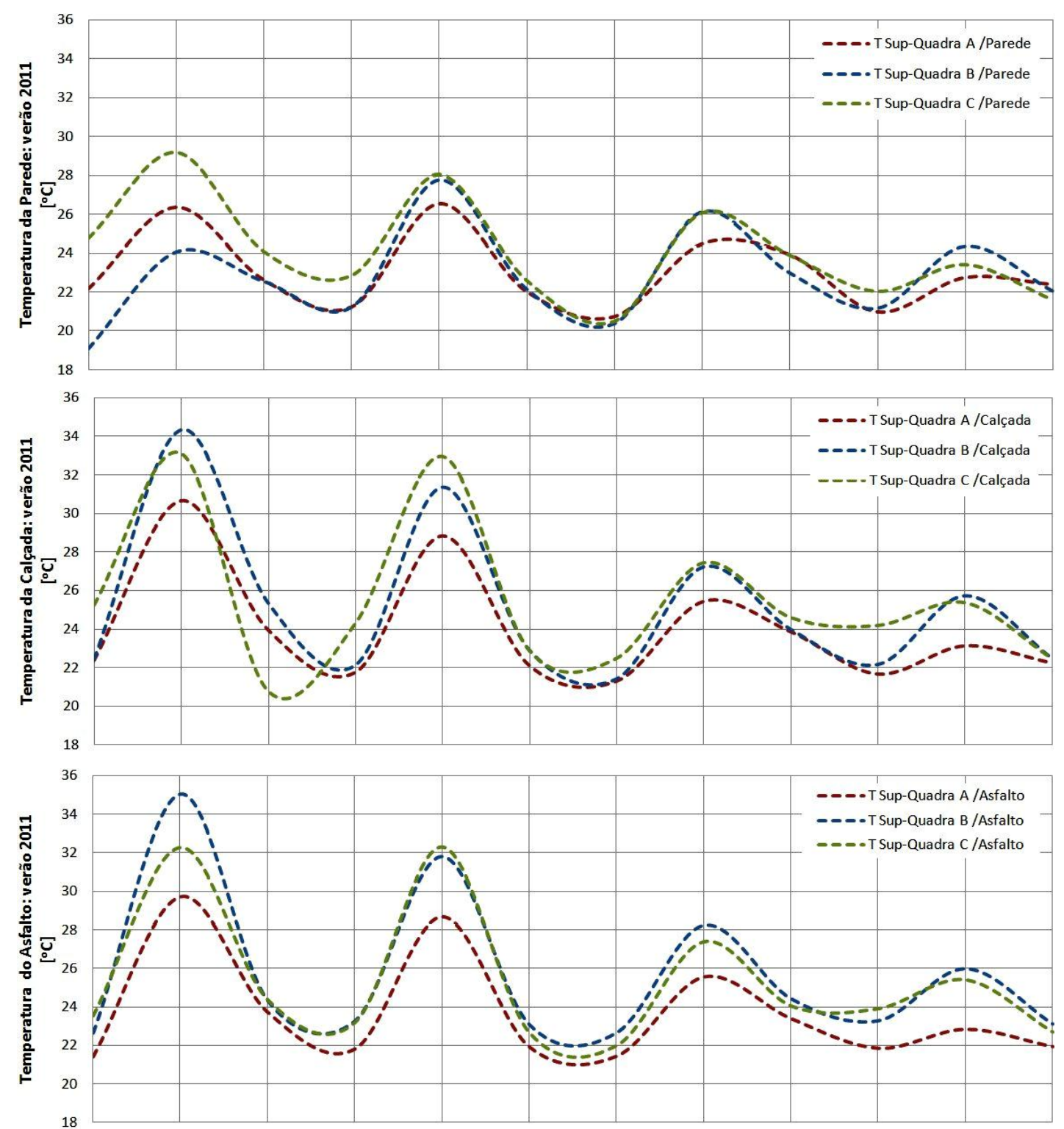


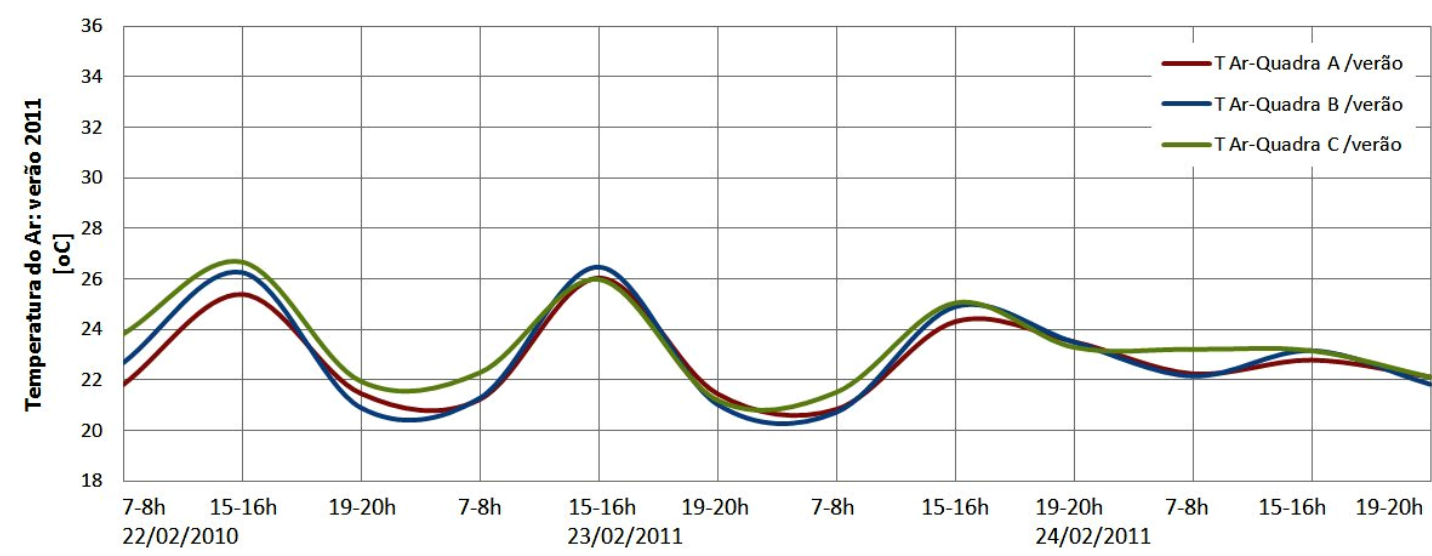

Figura 8. Curitiba/PR: Temperatura das superfícies (parede, calçada, asfalto) e do ar Verão/2011.
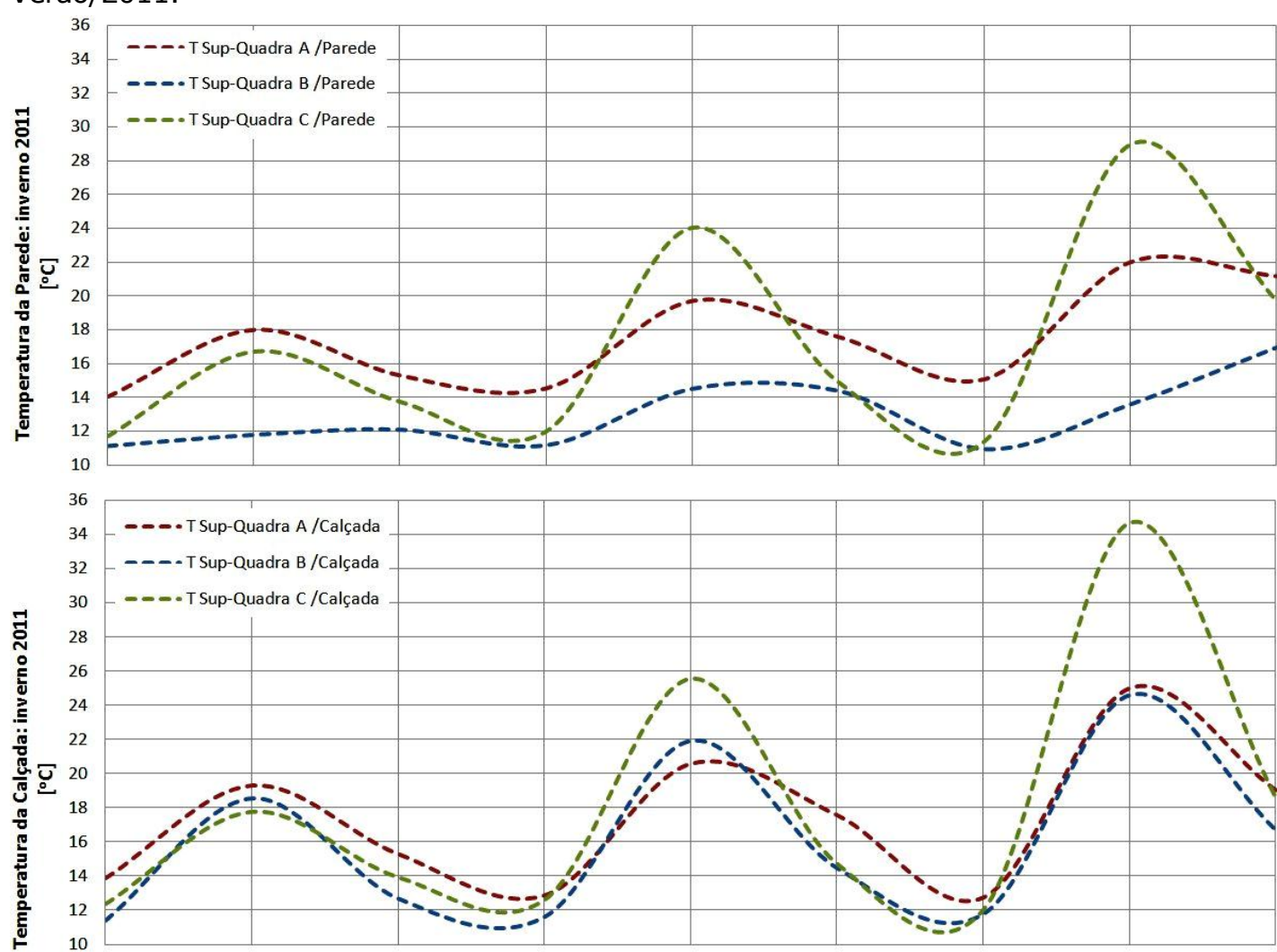

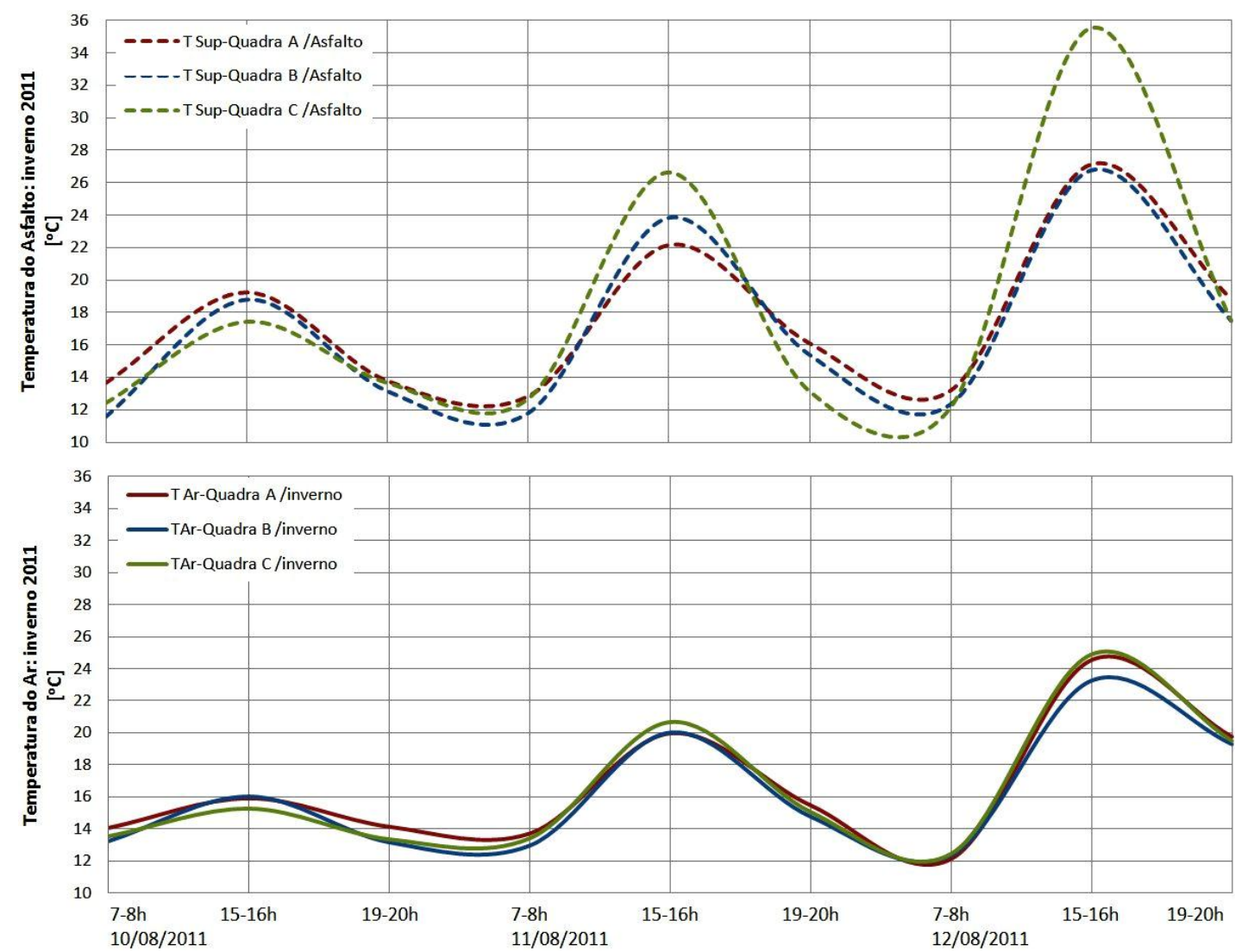

Figura 9. Curitiba/PR: Temperatura do ar e das superfícies (parede, calçada, asfalto) Inverno/2011.

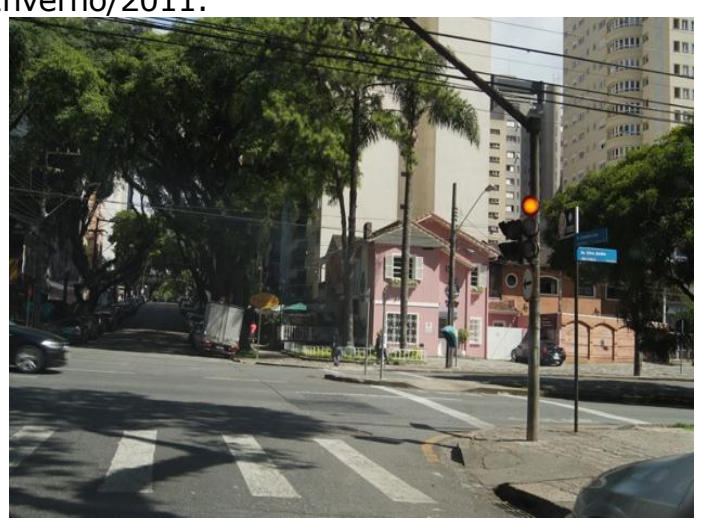

Figura 10. Curitiba/PR: Quadra A (Batel) caracterizada pela presença edifícios de múltiplos pisos e farta arborização de grande porte nas vias.

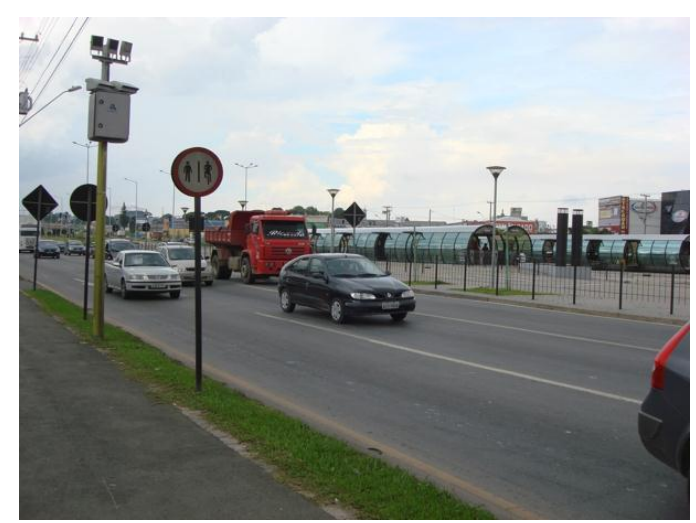

Figura 11. Curitiba/PR: Quadra C (Linha Verde) caracterizada pela presença armazéns e barracões de até 2 pavimentos, tráfego intenso e vastas superfícies impermeabilizadas.

Com respeito ao vento (velocidade e direção) verificou-se que este era altamente influenciado pelo intenso fluxo de veículos característico das vias onde os levantamentos de dados foram feitos. Considerando-se que este é o 
fluxo do "urbano" no canopy layer, o vento do fluxo deverá ser comparado aos dados oficiais da meteorologia, sem fluxo de veículos, mostrando assim o efeito da urbanização.

\section{Cenários urbanísticos e perspectivas de conforto térmico}

Nos últimos 15 anos os planejadores urbanos vêm trabalhando no sentido de mitigar os efeitos das mudanças climáticas em Curitiba, mediante alterações nos parâmetros propostos para os diferentes zoneamentos: definição de percentual mínimo de permeabilidade no lote, controle da relação entre altura e afastamento das divisas, além de medidas complementares para a coleta e reaproveitamento das águas de chuva ou a previsão de cisternas de contenção de cheias quando não atendida a permeabilidade mínima do lote. A alteração do zoneamento e dos parâmetros de uso e ocupação permitiu a criação de novos eixos de adensamento e modificará a centralidade da capital, ordenando o crescimento e direcionando-o para o centro-sul/sudeste da cidade. Tais medidas somadas à implantação da Linha Verde e do Metrô curitibano propiciarão benefícios como a acomodação do crescimento populacional, maior mobilidade urbana, ampliação da capacidade do transporte coletivo, facilitando a circulação dos automóveis e possibilitando a recepção dos turistas que virão à cidade na Copa do Mundo de Futebol em 2014.

Considerando-se o papel indutor do transporte público que está em implantação na Linha Verde e no Eixo Estrutural Norte-Sul (Metrô), o cenário que se desenha é o da aceleração na ocupação dos terrenos ao longo desses eixos, conduzindo à saturação das quadras, à consolidação da tipologia dos cânions urbanos e maior alteração das características climáticas naturais. Estas áreas apresentam, conforme Dumke (2007, p.287), temperaturas elevadas devido à produção urbana de calor e à massa térmica das edificações. Todavia, não são as áreas mais verticalizadas do centro e dos setores estruturais que apresentam as temperaturas mais expressivas, 0 que pode ser explicado pelo sombreamento dos edifícios, reduzindo o aquecimento das superfícies pela radiação solar indireta (Figura 12). No entanto o aumento da massa térmica das edificações deverá resultar em uma menor amplitude térmica nestas áreas, pois os terrenos que hoje apresentam baixo aproveitamento deverão receber novas torres de 15 a 25 pavimentos que intensificarão a ocupação atual da Quadra A e sua vizinhança.

$\mathrm{Na}$ Figura 12 vê-se a Quadra A e vizinhança imediata com sua atual ocupação e nela, as edificações classificadas pela sua altura, partindo dos edifícios de 1 e 2 pavimentos em verde, chegando aos edifícios acima de 21 pavimentos em vermelho. Já na Figura 13 demonstra-se a possível substituição dos edifícios de 1 e 2 pavimentos por edifícios de até 10 pavimentos, representados em amarelo, nos terrenos hoje atingidos pela Zona Residencial 4 (que permite até 10 pavimentos com compra de potencial construtivo). Já nas quadras atingidas pelo Setor Estrutural (legislação cuja altura é regulada pelo cone de aproximação da aeronáutica) os edifícios de 1 e 2 pavimentos serão substituídos por torres normalmente entre 15 e 30 pavimentos; nesta simulação, todavia, optou- 
se por torres de 11 a 20 pavimentos apresentadas na cor laranja. Como resultado, observa-se claro adensamento e significativa redução na percepção da arborização que hoje ainda tem forte presença e influência no conforto térmico da área.

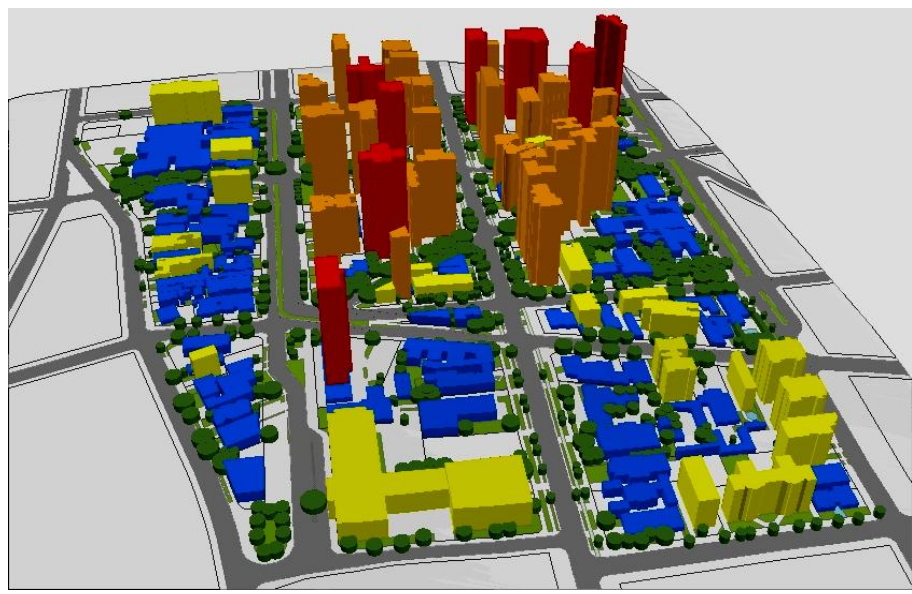

\section{Altura das Edificações}

Legenda:

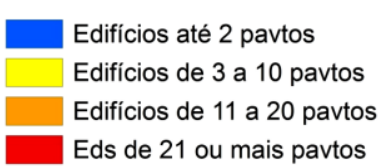

Figura 12. Curitiba/PR: Tipologia edificada atual da Quadra A (bairro Batel) e vizinhança.

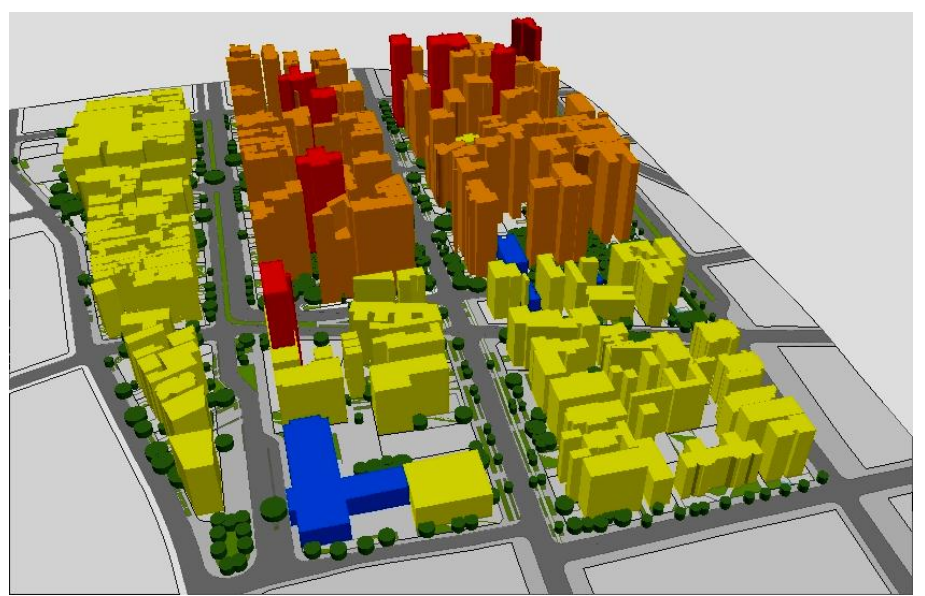

\section{Altura das Edificações}

\section{Legenda:}

Edifícios até 2 pavtos

Edifícios de 3 a 10 pavtos

Edifícios de 11 a 20 pavtos

Eds de 21 ou mais pavtos

Figura 13. Curitiba/PR: Tipologia edificada futura da Quadra A (bairro Batel) e vizinhança.

No caso da futura ocupação da Linha Verde, cuja ocupação atual está ilustrada na Figura 14, a legislação que passou a regular o uso e ocupação da área induzirá a uma tipologia semelhante à dos setores estruturais: mais verticalizada, portanto com maior sombreamento das superfícies. Primeiramente, a introdução de novos usos (especialmente o habitacional, comércio e serviço vicinal, de bairro e setorial) poderá induzir a substituição gradual dos grandes barracões (ocupados por atacadistas, oficinas mecânicas, transportadoras de mercadorias, venda de peças 
automotivas, etc.) e amplas áreas de estacionamento, por usos mais diversificados e de menor porte.

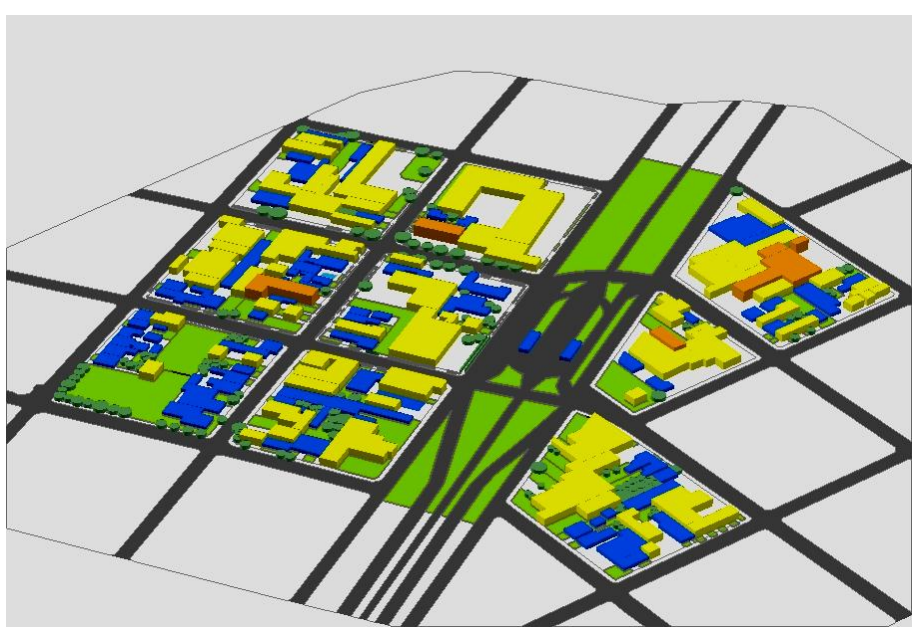

Figura 14. Curitiba/PR: Tipologia edificada atual na Quadra C (Linha Verde) e vizinhança.

\section{Altura das Edificações}

Legenda:

Edifícios térreos

Edifícios de 2 pavtos

Edifícios de 3 pavtos

A Linha Verde, assim como a Quadra C e sua vizinhança, apresenta duas Zonas de Uso e Ocupação do Solo: Setor Especial da BR-116 e Zona de Transição da BR-116, nos quais há limitação de altura (12 no Setor Especial da BR-116 e 6 pavimentos na Zona de Transição da BR-116), determinação de tamanho dos lotes e especificação de diferentes usos. Tais parâmetros, combinados, deverão promover a gradual substituição dos barracões de indústrias, de comércio atacadista e serviços pesados, por edifícios habitacionais, de serviços e comércio vicinal. A nova tipologia edificada será semelhante à presente na Quadra A (torres residenciais e de múltiplo uso) na área atingida pelo Setor Especial da BR116, e semelhante à da Quadra B (edifícios residenciais de 6 pavimentos) na área atingida pela Zona de Transição da BR-116.

A nova tipologia edificada (Figura 15) embora de predominância vertical, impõe afastamentos (um sexto da altura - h/6) e limita o número de pavimentos, devendo favorecer especialmente a insolação, a ventilação entre as edificações e a dispersão de gases, e também, em decorrência da redução dos caminhões, reduzir os problemas acústicos. Some-se a isso a presença de vegetação (rasteira, arbustiva e de grande porte) introduzida fartamente ao logo da via e nos vários bolsões ajardinados que a caracterizam e que estará crescida em alguns anos. As figuras 14 e 15 apresentam o cenário atual e o futuro da Quadra C e vizinhança, mostrando a atual tipologia edificada de grandes galpões e a tipologia futura de edifícios de 6, 8 e 12 pavimentos.

Destarte, no caso da Linha Verde, área que registrou as mais altas temperaturas observadas nas medições de inverno e verão, deverá haver uma diminuição destas tanto pela mudança de uso e tipologia edificada como pela introdução de farta vegetação. A umidade relativa não cairá abruptamente com a baixa nebulosidade, a amplitude térmica tenderá a ser menor, e a dispersão de poluentes, a ventilação, a redução da poluição acústica deverão 
também ser favorecidos pelas novas características da área.

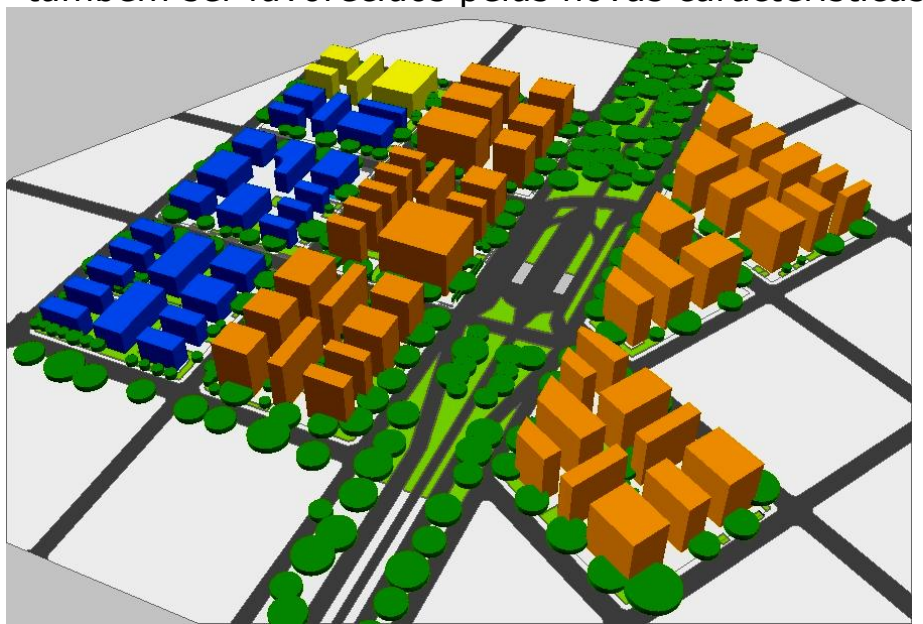

\section{Altura das Edificações}

Legenda:

Edificios até 6 pavtos Edifícios de 7 e 8 pavtos

Edifícios de 9 a 12 pavtos

Figura 15. Curitiba/PR: Tipologia edificada futura na Quadra C (Linha Verde) e vizinhança.

Desta forma, a área da Linha Verde tende a um cenário de maior massa edificada, maior presença de vegetação de grande porte, menor exposição das superfícies à radiação solar direta, menor fluxo de caminhões, promovendo o abrandamento de algumas das características observadas hoje: grande amplitude térmica nos dias de pouca nebulosidade, baixa umidade relativa e altas temperaturas, alto nível de poluição por dispersão de poluentes e acústica.

\section{CONCLUSÃO}

Sendo o clima urbano um modelo das modificações climáticas não intencionais que as ações humanas engendram no ambiente, a compreensão dos seus mecanismos e efeitos tanto sobre o ser humano como sobre a natureza é fundamental para a conformação do clima futuro. Neste sentido, o estudo da dinâmica de uso e ocupação do espaço urbano e da sua estreita relação com a formação de ICs, é determinante para que se possam tomar medidas de mitigação deste fenômeno cujas consequências são vivenciadas diariamente nas cidades brasileiras: situações de temperaturas extremas, tempestades, alagamentos e todo tipo de prejuízo decorrente. O cuidadoso estudo dos parâmetros de uso e ocupação do solo, a escolha dos materiais de construção e pavimentação de menor condutividade térmica, menor capacidade calorífica e maior refletância solar, assim como a manutenção da vegetação, especialmente de grande porte, podem contribuir para mitigar os efeitos das ICs.

Durante as etapas de levantamento de dados, tanto no verão como no inverno, foi possível vivenciar o clima intraurbano nas quadras escolhidas e antes mesmo do processamento dos dados e obtenção dos primeiros resultados, perceber a interação dos elementos do clima e do espaço urbano. Os dados levantados evidenciaram a alta relação entre nebulosidade, umidade e temperatura e explicitaram o que vivenciamos no 
local: a intensificação das ICs nos dias calmos e claros, seguidas em alguns dias, por inversões térmicas após a ocorrência de tempestades de verão.

Os dados destacaram a importância do sombreamento, especialmente aquele proporcionado pela arborização tanto nos lotes como nas vias, pois na Quadra A, onde há farta arborização, todos os resultados foram mais favoráveis. Os valores de temperatura do ar máximos no verão e mínimos no inverno foram mais brandos, os valores de temperatura das superfícies também se apresentaram mais brandos, a amplitude térmica foi menor tanto no verão como no inverno e a umidade relativa manteve-se mais estável, reduzindo-se em menor proporção e de modo mais gradual nas medições com baixa nebulosidade.

Considerando-se, portanto, os resultados parciais e confrontando-os com as mudanças propostas para a Linha Azul do Metrô ou a Linha Verde, os cenários que se apresentam para estes eixos apontam para uma pequena melhora no clima intraurbano das áreas estudadas, especialmente na Linha Verde, hoje extremamente árida. As diferenças mais significativas no cenário futuro serão verificadas na Linha Verde: mudança do uso dominante de serviços para residencial, na tipologia edificada dos barracões com grandes pátios de estacionamento para edifícios de menor área e com mais pavimentos, e, especialmente na introdução de mais área vegetada, tanto por força da reurbanização da via como por força da taxa de permeabilidade mínima exigida por lote. Já no caso da Linha Azul do Metrô, as mudanças mais sentidas deverão ser: a substituição das edificações de 1 e 2 pavimentos por torres de 15 ou mais pisos e a reurbanização da área da canaleta onde passam os biarticulados com significativa redução de poluição do ar e acústica.

\section{REFERÊNCIAS}

.ABNT - ASSOCIAÇÃO BRASILEIRA DE NORMAS TÉCNICAS. NBR 15220-3: Desempenho térmico de edificações - Parte 3: Zoneamento bioclimático brasileiro e diretrizes construtivas para habitações unifamiliares de interesse social. Rio de Janeiro, 2005.

.ASSIS, Eleonora Sad. Critérios de acessibilidade ao Sol e à luz natural para conservação de energia em escala urbana. In: ENCONTRO NACIONAL DE TECNOLOGIA NO AMBIENTE CONSTRUÍDO - ENTAC, 4. 2002, Foz do Iguaçu. Anais do... Foz do Iguaçu: ANTAC, 2002.

.ASSIS, Eleonora Sad. Impactos da forma urbana na mudança climática: Método para a previsão do comportamento térmico e melhoria de desempenho do ambiente urbano. Tese (Doutorado). Universidade de São Paulo. São Paulo, 2000.

.BAKONYI, S. M. C; DANNI-OLIVEIRA, I. M.; MARTINS, L. C.; BRAGA, A. L. F. Poluição atmosférica e doenças respiratórias em crianças na cidade de Curitiba, PR . Rev. Saúde Pública 38(5): 695-700, GRA, TAB. 2004 Oct.

COMEC - Coordenação da Região Metropolitana de Curitiba, 2010. Ocupação da RMC. Disponível em: <http://www.comec.pr.gov.br>. Acesso em 10 jul. 2010.

.DANNI-OLIVEIRA, I. M. A cidade de Curitiba e a poluição do ar: implicações de seus atributos urbanos e geoecológicos na dispersão de poluentes em período de inverno. Tese (Doutorado em Geografia). Universidade de São Paulo. São Paulo, 2000.

.DUMKE, Eliane. Clima urbano e condições de vida na cidade, uma perspectiva a partir do Aglomerado Urbano da Região Metropolitana de Curitiba - PR. Tese (Doutorado em Meio Ambiente e Desenvolvimento), UFPR. Curitiba, 2007.

.ESCOUROU, G. Le climat et la ville. Paris, Nathan, 1991. 
.GEIGER, R. Manual de Microclimatologia o clima da camada de ar junto ao solo. 2. ed. Lisboa: Fundação Calouste Gulbenkian, 1990. 556p.

.GIVONI, B. Comfort, climate analysis and building design guidelines. In: Energy and Buildings, v.18, p. 11-23, 1992.

.GOULART, S.; LAMBERTS, R.; FIRMINO, S. Dados climáticos para projeto e avaliação energética de edificações para 14 cidades brasileiras. Florianópolis: PROCEL/Núcleo de Pesquisa em Construção; UFSC, 1998.

.IPPUC - Instituto de Pesquisa e Planejamento Úrbano de Curitiba. Caracterização de Curitiba. Disponível em: <http://www.ippuc.org.br>. Acesso em 25 jan. 2011.

.MARENGO, J.A. Mudanças climáticas: detecção e cenários futuros para o Brasil até o final do século XXI. In: CAVALCANTI, I.F.A. (Org.) et al. Tempo e clima no Brasil. São Paulo: Oficina de textos, 2009, p.407-408.

.MENDONÇA, F. Effects of global warming on human health: An approach from "re-emergient" deseases in Brazil. In: DIAS, Pedro Leite da Silva; RIBEIRO, Wagner Costa; NUNES, Luci Hidalgo. (Org.). A contribution to understanding the regional impacts of global change in South America. 1 ed. São Paulo: Editora do IEA/USP, 2007, v. 1, p. 217-238.

.MENDONÇA, F.; DUBREUIL, V. Termografia de superfície e temperatura do ar na RMC (Região Metropolitana de Curitiba). Revista RA'E GA, Curitiba, Editora UFPR, n. 9, p. 25-35, 2006.

.MENDONÇA, F; DANNI-OLIVEIRA, I. M. Climatologia: noções básicas e climas do Brasil. v. 1. São Paulo: Oficina de Texto, 2007. 206 p.

.METRÔ CURITIBANO. Linha Azul CIC Sul/Santa Cândida. Traçado. Disponível em: <http://metro.curitiba.pr.gov.br>. Acesso em: 03/02/2011.

.MOLION, L. Variabilidade e forçantes climáticas. In: Congresso Brasileiro de Meteorologia, 14. Anais... 2006. Florianópolis, 2006.

.MONTEIRO, C. A. de F. Teoria e Clima Urbano. In: MONTEIRO, C. A. de F; MENDONÇA, F. (Org.) et al. Clima urbano. São Paulo: Contexto, 2003. p. 9-67.

A cidade como processo derivador ambiental e estrutura geradora de um "clima urbano". GeoSul, Florianópolis, Edufsc, n. 9, ano 5, p. 80-114, 1990.

.MOURA, R. Arranjos urbano-regionais no Brasil: uma análise com foco em Curitiba. Tese de Doutorado (Pós-Graduação em Geografia), UFPR. Curitiba, 2009, 242p.

.OKE, T. R. Street design and urban canopy layer climate. In: Energy and Buildings, New York: Elsevier, n. 11, p. 103-113, 1988.

.OKE, T.R. Air polluition in the boundary layer. In: Boundary layer climates. London: Mathuen \& Co, 1978, Chap. 9, 371 p.

.PREFEITURA MUNICIPAL DE CURITIBA. Plano Municipal de Mobilidade Urbana e Transporte Integrado. Curitiba: PMC, 2008.

.ROSSI, F; DUMKE, E; KRÜGER, E. Atualização do ano climático de referência para Curitiba. In: X Encontro Nacional de Conforto do Ambiente Construído (ENCAC), 2009, Natal RN. Anais do X ENCAC. Porto Alegre RS: Associação Nacional de Tecnologia do Ambiente Construído (ANTAC), v. 1. p. 1-10, 2009.

.SANTOS, Milton; SILVEIRA, Maria Laura. O Brasil: Território e sociedade no início do século XXI. $12^{a}$ ed. Rio de Janeiro/São Paulo: Record, 2008.

.SUGA, M. Avaliação do potencial de aproveitamento de luz natural em cânions urbanos: estudo realizado nos Eixos Estruturais de Curitiba. Dissertação (Mestrado em Tecnologia) Centro Federal de Educação Tecnológica do Paraná, Curitiba, 2005.

WHO. Impact of climate change on health: how to address new threats now. Fact sheet EURO/15/05. http://www.euro.who.int/Document/Mediacentre/fs1505e.pdf, 2005. 